\title{
USING GENETIC ALGORITHM IN MAKING OPTIMAL CONTROL DECISIONS
}

\author{
KLAUDIUSZ MIGAWA' \\ University of Technology and Life Sciences in Bydgoszcz
}

\section{Summary}

The problems presented in this article deal with operation process control in complex systems of technological object operation. Making appropriate control decisions directly influences the possibility of correct and effective carrying out of tasks assigned to the system. The paper presents a method of determining the optimal strategy for control of technological object operation process on the basis of genetic algorithm. In the presented method, determining of optimal strategy for control of technological object operation process involves the choice of a sequence of control decisions made in individual states of the modeled operation process. The method involves a choice, out of the possible decision options, of the best strategy for operation process control for which the function constituting the evaluation criterion has extreme value. Depending on one's needs, the genetic algorithm including the obtained model of operation process may be implemented for mathematic formulation and solution of a wide array of problems connected with control of complex systems of technological object operation. It pertains mostly to the economic analysis, risk management and safety management of complex systems of technological object operation. The paper presents an example of determining optimal strategy for control (decision sequence) when the criterion function includes availability of means of transport used in a selected operation system.

Keywords: operation process, control decisions, genetic algorithm

\section{Introduction}

Correct and effective functioning of complex technological object operation systems is possible only when control decisions made by system decision makers are rational. In systems where a complex technological object operation process is carried out, the choice of rational control decisions from among the possible decision options is a difficult and complicated issue. In virtual complex systems of technological object operation, decision making process should be carried out with the use of appropriate methods and mathematic tools, not in an 'intuitive' way, based only on the knowledge and experience of the system decision makers. Using appropriate mathematic methods for operation process control facilitates the choice of rational control decisions in a way that assures correct and effective carrying out of tasks assigned to the system.

1 University of Technology and Life Sciences, 7 Prof. S. Kaliskiego Street, 85-789 Bydgoszcz, Poland, e-mail: km@karor.com.pl, ph. +48523408424 
In the case of complex technological object operation systems, in order to determine the optimal strategy for operation process control it is necessary to implement appropriate and effective methods and mathematic tools. The paper presents genetic algorithm as an example of a tool supporting the process of determining the optimal control strategy.

In technical literature one may find numerous studies dealing with the theoretical description as well as examples of practical uses of genetic algorithm in searching for optimal solution, i.e.: $[1,3,9,10,12,13,14]$. The genetic algorithm belongs to the group of non-determinist methods of determining the optimal solution in which particular solutions are random modifications of previous solutions and are parts of them in a significant manner. The basic assumption for using genetic algorithm in searching for an optimal solution is the fact taken from evolution theory claiming that the greatest probability of modification involves solutions with the greatest degree of adaptability defined by the fitness function (optimization task objective function).

Genetic algorithm may serve as a convenient tool the implementation of which facilitates the use of a complicated rational control decision making process in complex technological object operation system.

\section{Description of genetic algorithm operation}

For the description of the operation of genetic algorithm presented in the article, terminology generally used in technical literature was used, while, at the same time reflecting names and terms connected with optimal strategy for technological object operation process:

- gene (decision) - individual element of the chromosome - while looking for optimal strategy, defined by a specific decision made in a given decision-making state of the analyzed operation process;

- chromosome (strategy) - an object representing crucial variables in the process of looking for optimal solution (eg. optimal strategy). It consists of an ordered gene sequence (decision) and constitutes an encoded form of possible solutions (permissible strategies);

- population - chromosome set (strategy set). Population size is preliminary established and remain constant during the calculation procedure. During the operation of the algorithm elements of the population (chromosomes) undergo modification according to the preliminary accepted scheme so that, after modification, they maintain certain features of the elements (chromosomes) from earlier populations and as a result of the operation of the random factor;

- fitness function - objective function or a function connected with objective function in the process of looking for optimal solution (optimal strategy). It makes a numerical evaluation of the adaptability of individual elements (strategies) possible. 
Figure 1 presents a general chart of the operation of the genetic algorithm in the case of determining optimal strategy $\delta *$ for control of technological object operation process.

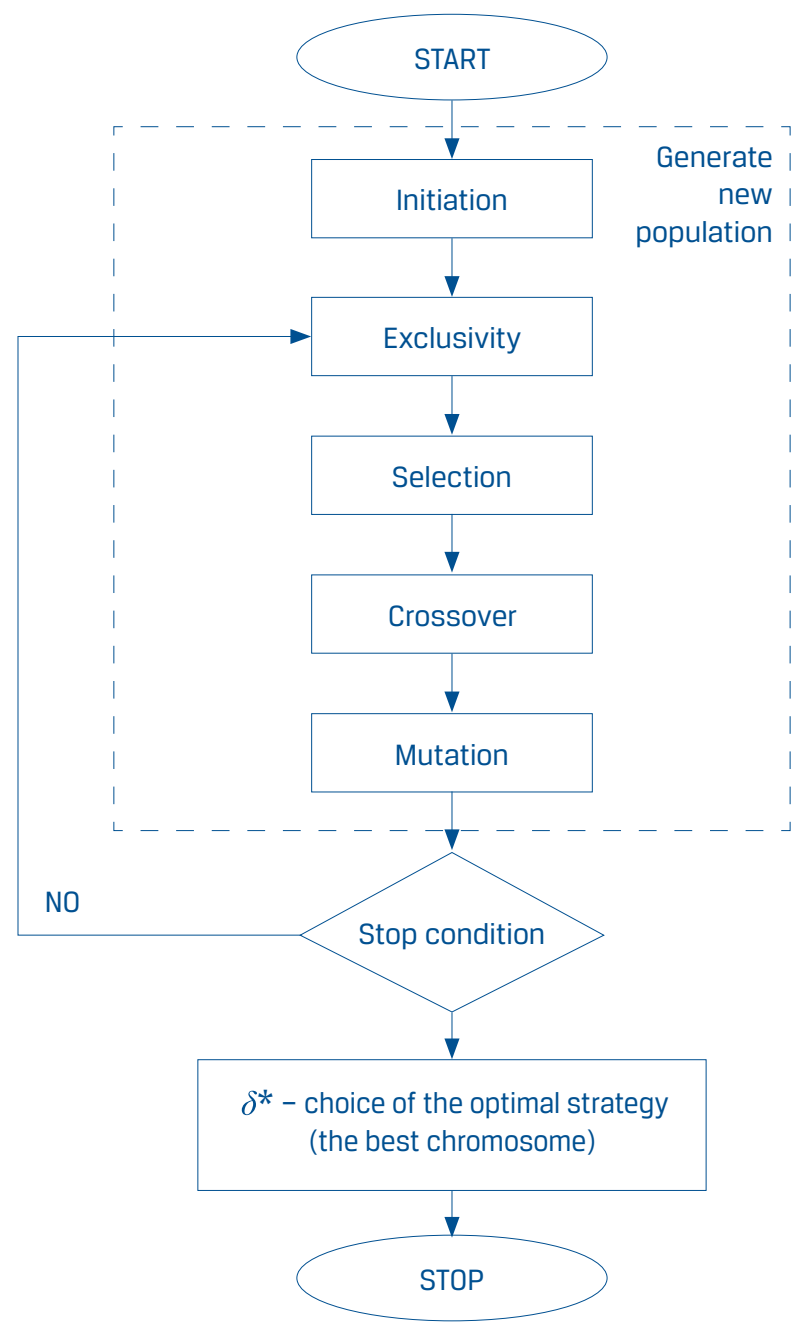

Fig. 1. Scheme of the genetic algorithm of choice of the optimal strategy $\delta^{*}$ 
The following stages of genetic algorithm operation are presented below:

\section{Stage I - INITIATION}

Initiation is an initial stage of the carrying out of genetic algorithm. At this stage, establishing of the basic parameters of the algorithm and of the rules of encoding of optimization variables, determining of initial population, outlining fitness functions as well as determining the value of fitness function value for individual chromosomes ( $\delta$ strategies) of initial population all take place.

\section{Stage I.a - Determining basic parameters of genetic algorithm}

The basic parameters of genetic algorithm are as follows:

- length $m$ of the chromosome, determined by the number of genes in the chromosome. The number of genes in the chromosome equals the number of the analyzed crucial variables in the given optimization task;

- $\quad$ population size $n$, or the number of chromosomes in the population. Due to the precision and credibility of results, an appropriate choice of the number of chromosomes in the population is an important problem. The number of chromosomes in the population should not be too small, as it limits the possibility of population evolution, and, as a result, the analyzed (searched) solution subset becomes narrowed down in successive iterations (for successive populations). On the other hand, a very large population may cause significant prolongation of calculation periods in successive iterations. The number of chromosomes in the population depends on both the length of chromosome and the implemented encoding method;

- $\quad \eta$ factor - determining the probability of selecting chromosomes on the basis of elitism. The principle of elitism pertains to the choice of the best adapted chromosomes belonging to the previous population and copying them for the new population. Depending on the size of the created new population, one or several best adapted are copied from previous population;

- $\quad \kappa$ factor - determining the probability of hybridization. Hybridization involves exchange of genes between chromosomes coming from individual parent pairs. As a result of the hybridization operation, the chromosomes of the offspring are created, a combination of genes of respective pairs of parent chromosomes;

- $\mu$ factor - determining the probability of mutation. Mutation is the final stage of chromosome generation in the new population and pertains to the change of individual genes of the chromosome of the offspring created at the stage of hybridization completely at random. 


\section{Stage I.b - Determining optimization variable encoding rules}

While choosing the encoding method, several basic rules should be taken into account:

- using a chosen encoding method one needs to take into consideration that it only makes it possible to encode a finite number of elements from the acceptable solutions (chromosomes) set, determined by the number of possible chromosomes and their length (the number of genes in a chromosome);

- the chosen method must unequivocally make it possible to identify the individual elements of the acceptable solutions (chromosomes) set;

- the chosen method should eliminate the possibility of creating, as a result of genetic algorithm operation, a chromosome without an equivalent in the set of acceptable solutions.

While using genetic algorithm, from among the numerous methods of optimization variables encoding, binary encoding is the one used the most often. The binary encoding method makes it possible to encode individual elements of acceptable solutions (chromosomes) so that the number of genes in a chromosome equals the number of analyzed crucial optimization variables. When using binary encoding method the establishing of the number of $m$ chromosome genes unequivocally determines the maximum number of chromosomes in the set of acceptable solutions, which amounts to $2^{m}$.

\section{Stage I.c - Determining initial (starting) population}

Having established basic optimization parameters as well as encoding rules, with the help of random method, the initial population $\Delta^{(0)}$ with $n$ number of elements (chromosomes) is generated in the form of the following sequence

$$
\Delta^{(0)}=\left\{\delta_{1}^{(0)}, \delta_{2}^{(0)}, \ldots, \delta_{n-1}^{(0)}, \delta_{n}^{(0)}\right\} .
$$

The order of drawn elements (chromosomes) in the population is arbitrary and there is a possibility of multiple occurrence of the same elements (chromosomes) in the same population.

\section{Stage I.d - Determining the value of fitness function for initial population}

Optimization of a given task with the use of genetic algorithm is possible only when we have the so-called fitness function at our disposal, for which it is possible to find maximum and minimum values (depending on the analyzed optimization task). A fitness function may be both an objective function and any function strictly connected with the objective function of the analyzed optimization task. Determining the value of fitness function 
makes it possible to numerically evaluate the adaptability of individual chromosomes in the analyzed population.

If in a given optimization task:

- the objective function $f_{C}$ is defined in set $X$, or $f_{C}: X \rightarrow R$,

- $\delta(x)$ means a chromosome unequivocally identifying element $x \in X$,

- - a set of acceptable solutions $Y$ is determined, being a subset of set $X$.

Then the function $f_{P}: \Delta \rightarrow R$ is a fitness function of the analyzed optimization task, where $\Delta$ means a chromosome set of $m$ length, consisting of binary genes $d_{j} \in\{0,1\}, j=1,2, \ldots, m$, defined as follows:

$$
\Delta=\{\delta(x): x \in Y\},
$$

where:

$$
\delta(x)=\left[d_{1}, d_{2}, \ldots, d_{m}\right]: d_{j} \in\{0,1\}, j=1,2, \ldots, m .
$$

The fitness function $f_{P}: \Delta \rightarrow R$ thus determined may be an equivalent of the objective function $f_{C}: X \rightarrow R$ in the following form:

- in the case of objective function maximization

$$
f_{P}(\delta(x))=f_{C}(x),
$$

- in the case of objective function minimization

$$
f_{P}(\delta(x))=-f_{C}(x) .
$$

The value of fitness function $f_{P}(\delta(x))$ may be determined when the relation between chromosome set $\Delta$ and acceptable solution set $Y$ as well as the relation between fitness function $f_{P}(\delta(x))$ and the objective function $f_{C}(x)$ are known. 


\section{Stage II - GENERATING POPULATIONS IN SUCCESSIVE ITERATIONS}

The basic assumption in optimization method with the use of genetic algorithm is for the chromosome populations generated in successive iterations to be better adapted than chromosome populations generated in previous iterations. It means that the determined values of fitness function $f_{P}(\delta(x))$, for successive generated chromosomes are larger and larger when looking for maximum and smaller and smaller when looking for minimum.

The result of carrying out of this stage is generation of elements (chromosomes) of new populations $\Delta^{(I)}$ (created in successive iterations $I$ ) out of elements (chromosomes) of previous populations $\Delta^{(I-1)}$. The method of generating elements of new populations involves $n$-fold drawing of $n$ chromosome pairs, the so-called parent pair, and then creating $n$ offspring of the new population as a result of $n$-fold use of successive operations: selection, hybridization and mutation. As a result of hybridization and mutation operations, the selected chromosomes are suspect to random modifications which may cause the risk of losing the best adapted chromosome from the previous population. Because of that, the so-called elitism principle is used in practice.

\section{Stage II.a - Elitism}

According to elitism principle at least one form among the best adapted chromosomes is copied for the new population. When using genetic algorithm, in order to assure a better and better adaptability of successive populations one assumes that the greatest influence over the new populations should be exerted by elements (chromosomes) belonging to previous population for which fitness functions asserted the highest values. According to this assumption, weakly adapted chromosomes should not end up in the newly created population.

Elitism principle involves the choice of the best (best adapted) elements (chromosomes) from out of the elements (chromosomes) of previous population and copying them to new populations. The number of copied chromosomes may differ. Most often it is assumed that one or more of the best adapted chromosomes are copied from previous population. Elitism principle makes a better functioning of genetic algorithm possible and involves the fact that the best result (the best adapted chromosome) is remembered (copied to successive populations) as long as a better solution is found - a chromosome, for which the value of the function is higher.

For the choice of elements to be copied to new populations, random methods are often used. Then, a value for the $\eta$-factor is determined, defining the probability of the choice of chromosomes based on elitism principle. It means that the chromosomes to be placed in the new population are chosen according to the rule of elitism with $\eta$ probability, while choosing based on the rule of selection, hybridization and mutation with $1-\eta$ probability. 


\section{Stage II.b - Selection}

The goal for the stage of selection is the choice of such chromosomes from out of the chromosomes of the previous population, which at the stage of hybridization will create the so called parent chromosome pairs. Chromosome selection is a random process in which the choice of parent pair should be significantly influenced by the given chromosome having desirable features (fitness function value). It means that if a given chromosome is assigned a better (higher or smaller, respectively) value of fitness function, the probability of drawing this chromosome for the parent pair should be higher. One of the simplest and most often used drawing methods at this stage is the so-called roulette wheel method which meets the condition of proportionality of the chance to draw a given chromosome for the value of fitness function assigned to it.

\section{Stage II.c - Hybridization}

The objective of hybridization operation is transferring of the features of individual parent chromosome pairs (chosen at selection stage) to the offspring chromosomes, newly created at the stage of hybridization. Hybridization operation involves an exchange, with the help of specific hybridization operator, of genes between chromosomes coming from individual parent pairs. As a result of carrying out of hybridization operation, offspring chromosomes are created as certain combinations of genes of appropriate parent chromosome pairs.

In order to ascertain whether hybridization operation is implemented, the value of the factor is set at $\kappa \in\langle 0,1\rangle$, determining the probability of hybridization taking place. Then, for each of the parent chromosome pairs (from previous population) the number $x \in\langle 0,1\rangle$ is drawn. Hybridization operation, for the given parent chromosome pair, is carried out when the value of the drawn number $x<\kappa$. Nevertheless, when $x \geq \kappa$, hybridization is not carried out and one of the parent chromosomes (selected by drawing) is copied to the successive population. It is worth noticing that for $\kappa=0$ hybridization is never carried out, while for $\kappa=1$ it is carried out very often (hybridization will be carried out for the majority of parent chromosome pairs).

The correct choice of the method of hybridization influences the correctness of the operation of genetic algorithm. Unfortunately, there is no single superior way of chromosome hybridization while the effectiveness of its selection depends on the analyzed objective function of the given optimization task. Many hybridization methods have been worked out, used in optimization with the use of genetic algorithm. Among the many available hybridization operators, the ones most often used in practice are:

- one point hybridization operator,

- two point hybridization operator,

- homogenous hybridization operator,

- AND hybridization operator,

- XOR hybridization operator,

- $\mathrm{BLX}-\alpha$ hybridization operator, 
- MIN-MAX hybridization operator,

- FCB hybridization operator.

\section{Stage II.d - Mutation}

Mutation is the final stage of generating elements (chromosomes) of the new population and involves the change of individual genes of the offspring chromosome created previously at the hybridization stage. Using mutation makes it possible to include among the elements of the new population also these chromosomes which, by definition, are practically impossible to obtain as a result of hybridization only (out of the elements of previous population).

At the stage of mutation the changes of individual genes are carried out in a completely random way. The values of the probability of the occurrence of mutation for individual chromosome genes are determined at the stage of the initiation of genetic algorithm. In order to tell whether the mutation operation is to be implemented, the value of the factor is set at $\mu \in\langle 0,1\rangle$, determining the probability of mutation occurrence. Then, for each $d_{j}$ gene of the analyzed chromosome (created at the stage of hybridization) the number $x_{j} \in\langle 0,1\rangle$ is drawn. Mutation of $d_{j}$ gene is carried out when the value of the drawn number $x_{j}<\mu$ . Nevertheless, when $x_{j} \geq \mu$, mutation of $d_{j}$ gene is not carried out. It is worth noticing that for $\mu=0$, hybridization is never carried out, while for $\mu=1$ it is carried out very often (mutation will be carried out for majority of genes).

\section{Stage III - STOP CONDITION}

When the choice of optimal strategy (superior chromosome) is made on the basis of genetic algorithm, it is possible to implement two stop conditions:

- Attaining the assumed number of iterations,

- Small changes of the value of objective function (fitness function) determined for the strategy (chromosome) best adapted among the elements of the tested populations within the course of successive iterations.

\section{The choice of the optimal control strategy for the operation process of technical objects}

Due to the random nature of the factors influencing the running of the technical objects (transport means) operation process introduced in a complex system, most often in the process mathematical modelling of the operation process, stochastic processes are used. Random process includes a wide implementation of Markov and semi-Markov process for modelling the operation process for technical objects, whereas in the case of the issues involving control of operation processes, decision-making Markov and semi-Markov processes are used $[2,4,5,6,7,8,11]$. 
Assuming that the analyzed model of technical object operation process is a random process $\{X(t): t \geq 0\}$ of finite number of process states $i=1,2, \ldots, m$, then:

$$
D_{i}=\left\{d_{i}^{(1)}\left(t_{n}\right), d_{i}^{(2)}\left(t_{n}\right), \ldots, d_{i}^{(k)}\left(t_{n}\right)\right\},
$$

means a set of all possible control decisions which can be implemented in $i$-state of the process at the moment of $t_{n^{\prime}}$ where $d_{i}^{(k)}\left(t_{n}\right)$ means $k$-control decision made in $i$-state of the process, at the moment of $t_{n}$.

In the case of optimization task involving the choice of optimal strategy of technical object operation process control from among the acceptable strategies, then as the strategy we understand the $\delta$ sequence, where the words are the vectors, comprising of the decision $d_{i}^{(k)}\left(t_{n}\right)$ made in the following moments of the $t_{n}$ changes of the state of the process $X(t)$ :

$$
\left.\delta=\left\{d_{1}^{(k)}\left(t_{n}\right), d_{2}^{(k)}\left(t_{n}\right), \ldots, d_{m}^{(k)}\left(t_{n}\right)\right]: \quad n=0,1,2, \ldots\right\} .
$$

The choice of appropriate control strategy $\delta$ called the optimal strategy $\delta$, concerns the situation, when the function representing the selection criterion of the optimal strategy takes an extreme value (minumum or maximum).

In order to determine the optimal control strategy (decision sequence) it is possible to implement decision-making semi-Markov processes. The decisive semi-Markov process is a stochastic process $\{X(t): t \geq 0\}$, the implementation of which depends on the decisions made at the beginning of the process $t_{0}$ and at the moments of changing the process $t_{1}, t_{2}, \ldots, t n, \ldots$ In case of implementation of the decisive semi-Markov processes making the decision at the moment of $t_{n^{\prime}} k$-controlling decision in $i$-state of the process means a choice of $i$-verse of the core of the matrix from the following set:

$$
\left\{Q_{i j}^{(k)}(t): t \geq 0, d_{i}^{(k)}\left(t_{n}\right) \in D_{i}, \quad i, j \in S\right\},
$$

where:

$$
Q_{i j}^{(k)}(t)=p_{i j}^{(k)} \cdot F_{i j}^{(k)}(t)
$$

The choice of the $i$-verse of the core of the process specifies the probabilistic mechanism of evolution of the process in the period of time $\left\langle t_{n} ; t_{n+1}\right)$. This means that for the semiMarkov process, in case of the change of the state of the process from one into $i$-one (entry to the $i$-state of the process) at the moment $t_{n^{\prime}}$ the decision is made $d_{i}^{(k)}\left(t_{n}\right) \in D_{i}$ and according to the schedule $\left(p_{i j}^{(k)}: j \in S\right) j$-state of the process is generated, which is entered at the moment of $t_{\mathrm{n}+1}$. At the same time, in accordance with the schedule specified by the distributor $F_{i j}^{(k)}(t)$, the length of the period of time is generated $\left\langle t \mathrm{n} ; t_{\mathrm{n}+1}\right)$ to leave the $i$-state of the process, when the next state is the $j$-state. 
In case of the implementation of the genetic algorithm to determine the optimal strategy of controlling the operation processes for technical objects, the following guidelines should be considered:

- $\quad$ the examined stochastic process is the $m$-state decisive semi-Markov process,

- in each state it is possible to implement one of the two ways of performance (called a decision),

- if the decisions are marked as 0 and 1 then the number of control strategies to be implemented for the $m$-state model of the operation process of the means of transport amounts to $2^{m}$,

- the set of control strategies is the set of functions:

$$
\delta: S \rightarrow D
$$

where:

$S$ - is the set of the states of the process, $S=\{1,2, \ldots, m\}$,

$D$ - is the set of decisions made in the states of the process, $D=\{0,1\}$.

On the basis of the following guidelines each possible control strategy can be presented as $m$-positioning sequence consisting of 0 and 1 . This is then the positioning binary number. Therefore, an exemplary control strategy for the model of the operation process consisting of $m=9$ states can be determined in the following way $\delta=[1,0,1,1,0,1,0,0,1]$.

\section{Example of determining optimal technical object operation process control strategies}

Presented below is an example of assigning optimal operation process control strategy carried out in the chosen transport means operation system - the city bus transport system. In the presented example, the criterion of determining optimal strategy $\delta^{*}$ constitutes the value of the function describing the availability of the technical object (transport means) $G^{O T}$. The choice of the optimal strategy $\delta^{*}$ is made on the basis of the following criterion:

$$
G^{O T}\left(\delta^{*}\right)=\max _{\delta}\left[G^{O T}(\delta)\right]
$$

The evaluation of the availability of transport means may be performed on the basis of mathematical model of the operation process carried out in the tested system of transport means (city buses) operation.

Due to the identification of the analyzed operation process of transport means, crucial operation states of the process as well as possible transfers between the defined states were designated. Based on this, a graph was created, depicting the changes of operation process states, shown in Figure 2. 


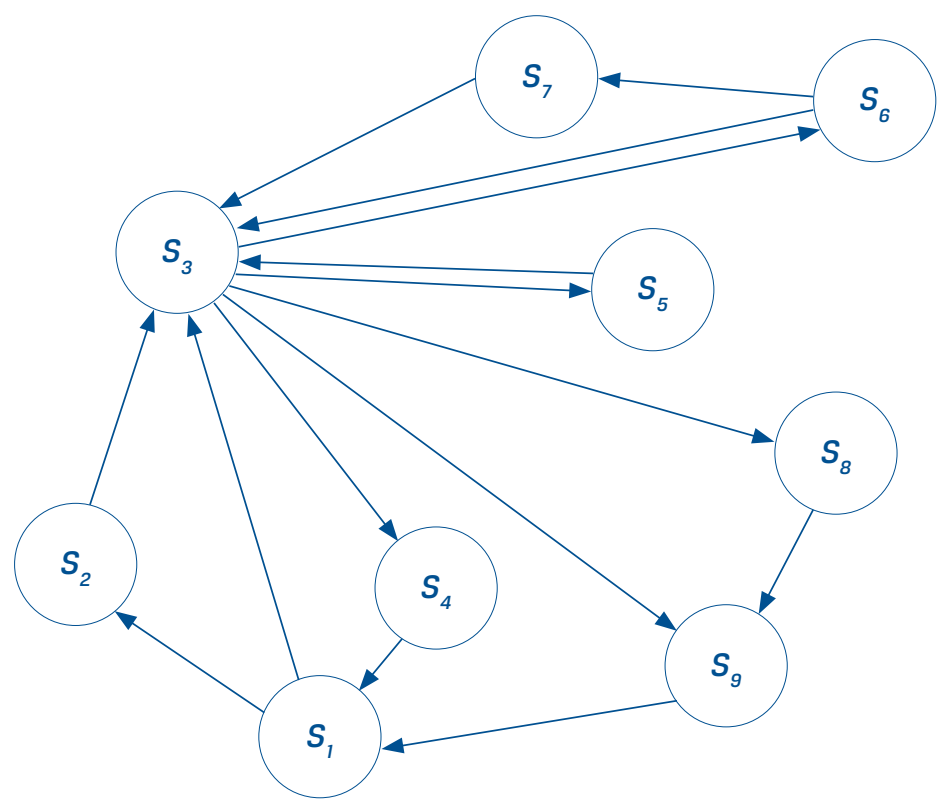

Fig. 2. Directed graph representing the transport means operation process

$S_{1}$ - refueling, $S_{2}$ - awaiting the carrying out of the task at the bus depot parking space, $S_{3}$ - carrying out of the transport task, $S_{4}$ - awaiting the carrying out of the task between transport peak hours, $S_{5}$ - repair by technical support unit without losing a ride, $S_{6}$ - repair by the emergency service with losing a ride, $S_{7}$ - awaiting the start of task realization after technical support repair, $S_{8}$ - repair in the serviceability assurance subsystem, $S_{9}$ - maintenance check on the operation day

The mathematical model of the analyzed transport means operation process was built with the use of the semi-Markov processes theory. The semi-Markov $X(t)$ process is one, where periods of time between the changes of consecutive process states have arbitrary probability distributions and a transfer to the consecutive state depends on the current process state. Using the semi-Markov processes in mathematical modelling of the operation process, the following assumptions were put forward:

- the modelled operation process has a finite number of states $S_{i}, i=1,2, \ldots, 9$,

- if technological object at moment $t$ is in state $S_{i^{\prime}}$ then $X(t)=i$, where $i=1,2, \ldots, 9$,

- the random process $X(t)$ being the mathematical model of the operation process is a homogenous process,

- at moment $t=0$, the process finds is in state $S_{3}$ (the initial state is state $S_{3}$ ), i.e. $P\{X(0)=3\}=1$. 
The homogenous semi-Markov process is unequivocally defined when initial distribution and its kernel are given. Form our assumptions and based on the directed graph shown in Figure 2 , the initial distribution $p_{i}(0), i=1,2, \ldots, 9$ takes up the following form:

$$
p_{i}(0)=\left\{\begin{array}{lll}
1 & g d y & i=3 \\
0 & g d y & i \neq 3
\end{array},\right.
$$

where:

$$
p_{i}(0)=P\{X(0)=i\}, \quad i=1,2, \ldots, 9
$$

whereas the kernel of process $Q(t)$ takes up the form:

$$
Q(t)=\left[\begin{array}{ccccccccc}
0 & Q_{12}(t) & Q_{13}(t) & 0 & 0 & 0 & 0 & 0 & 0 \\
0 & 0 & Q_{23}(t) & 0 & 0 & 0 & 0 & 0 & 0 \\
0 & 0 & 0 & Q_{34}(t) & Q_{35}(t) & Q_{36}(t) & 0 & Q_{38}(t) & Q_{39}(t) \\
Q_{41}(t) & 0 & 0 & 0 & 0 & 0 & 0 & 0 & 0 \\
0 & 0 & Q_{53}(t) & 0 & 0 & 0 & 0 & 0 & 0 \\
0 & 0 & Q_{63}(t) & 0 & 0 & 0 & Q_{67}(t) & 0 & 0 \\
0 & 0 & Q_{73}(t) & 0 & 0 & 0 & 0 & 0 & 0 \\
0 & 0 & 0 & 0 & 0 & 0 & 0 & 0 & Q_{89}(t) \\
Q_{91}(t) & 0 & 0 & 0 & 0 & 0 & 0 & 0 & 0
\end{array}\right]
$$

where:

$$
\begin{gathered}
Q_{i j}(t)=P\left\{X\left(\tau_{n+1}\right)=j, \tau_{n+1}-\tau_{n} \leq t \mid X\left(\tau_{n}\right)=i\right\}, i, j=1,2, \ldots, 9, \\
Q_{i j}(t)=p_{i j} \cdot F_{i j}(t), \\
p_{i j}(t)=P\{X(t)=j \mid X(0)=i\}
\end{gathered}
$$

means that the conditional probability of transfer from state $S_{i}$ to state $S_{j^{\prime}}$

$$
F_{i j}(t)=P\left\{\tau_{n+1}-\tau_{n} \leq t \mid X\left(\tau_{n}\right)=i, X\left(\tau_{n+1}\right)=j\right\}, i, j=1,2, \ldots, 9
$$

is a distribution function of random variable signifying period of duration of state $S_{i^{\prime}}$ under the condition that the next state will be state $S_{j}$. 
In order to assign the values of limit probabilities $p_{i}^{*}$ of staying in the states of semiMarkov model of transport means operation, the following were created: matrix $P$ of the states change probabilities and matrix $\Theta$ of conditional periods of duration of the states in process $X(t)$ :

$$
\begin{aligned}
& P=\left[\begin{array}{ccccccccc}
0 & p_{12} & p_{13} & 0 & 0 & 0 & 0 & 0 & 0 \\
0 & 0 & 1 & 0 & 0 & 0 & 0 & 0 & 0 \\
0 & 0 & 0 & p_{34} & p_{35} & p_{36} & 0 & p_{38} & p_{39} \\
1 & 0 & 0 & 0 & 0 & 0 & 0 & 0 & 0 \\
0 & 0 & 1 & 0 & 0 & 0 & 0 & 0 & 0 \\
0 & 0 & p_{63} & 0 & 0 & 0 & p_{67} & 0 & 0 \\
0 & 0 & 1 & 0 & 0 & 0 & 0 & 0 & 0 \\
0 & 0 & 0 & 0 & 0 & 0 & 0 & 0 & 1 \\
1 & 0 & 0 & 0 & 0 & 0 & 0 & 0 & 0
\end{array}\right], \\
& \Theta=\left[\begin{array}{ccccccccc}
0 & \bar{\Theta}_{12} & \bar{\Theta}_{13} & 0 & 0 & 0 & 0 & 0 & 0 \\
0 & 0 & \bar{\Theta}_{23} & 0 & 0 & 0 & 0 & 0 & 0 \\
0 & 0 & 0 & \bar{\Theta}_{34} & \bar{\Theta}_{35} & \bar{\Theta}_{36} & 0 & \bar{\Theta}_{38} & \bar{\Theta}_{39} \\
\bar{\Theta}_{41} & 0 & 0 & 0 & 0 & 0 & 0 & 0 & 0 \\
0 & 0 & \bar{\Theta}_{53} & 0 & 0 & 0 & 0 & 0 & 0 \\
0 & 0 & \bar{\Theta}_{63} & 0 & 0 & 0 & \bar{\Theta}_{67} & 0 & 0 \\
0 & 0 & \bar{\Theta}_{73} & 0 & 0 & 0 & 0 & 0 & 0 \\
0 & 0 & 0 & 0 & 0 & 0 & 0 & 0 & \bar{\Theta}_{89} \\
\bar{\Theta}_{91} & 0 & 0 & 0 & 0 & 0 & 0 & 0 & 0
\end{array}\right] .
\end{aligned}
$$

Based on the matrix $P$ and on the matrix $\Theta$, average values $\overline{\Theta_{i}}$ of non-conditional duration periods of process states were defined, according to the dependence:

$$
\overline{\Theta_{i}}=\sum_{i=1}^{9} p_{i j} \cdot \bar{\Theta}_{i j}, i, j=1,2, \ldots, 9 \text {. }
$$

Therefore, the boundary probability $p_{i}^{*}$ for staining in the states of the semi-Markov processes can be determined on the basis of the boundary statement for the semi-Markov process [2], in accordance with the following pattern:

$$
p_{i}^{*}=\lim _{t \rightarrow \infty} p_{i}(t)=\frac{\pi_{i} \cdot E\left(\Theta_{i}\right)}{\sum_{i \in S} \pi_{i} \cdot E\left(\Theta_{i}\right)},
$$

where probabilities $\pi_{i}, i \in S$ constitute the stationary layout of the implemented Markov's chain in the process which fulfils the system of linear equations: 


$$
\sum_{i \in S} \pi_{i} \cdot p_{i j}=\pi_{j}, \quad j \in S, \sum_{i \in S} \pi_{i}=1
$$

Availability of a single technical object defined on the basis of the semi-Markovian model of operational process is determined as the sum of limit probabilities $p_{i}{ }^{*}$ of remaining at states belonging to the availability states set:

$$
G^{O T}=\sum_{i} p_{i}^{*}, \quad d l a \quad S_{i} \in S_{G} .
$$

In order to define availability of technical objects (means of transport) based on the semiMarkovian model of operational process, the operational states of the technical object should be divided into availability states $S_{G}$ and non-availability states $S_{N G}$ of the object for the carrying out of the assigned task. In the presented model, the following technical object availability states were enummerated:

- state $S_{2}$ - awaiting the carrying out of the task at the bus depot parking space,

- state $S_{3}$ - carrying out of the transport task,

- state $S_{4}$ - awaiting the carrying out of the task between transport peak hours,

- state $S_{7}$ - awaiting the start of task realization after technical support rep air.

Then, with the use of the MATHEMATICA software, the limit probability $p_{i}{ }^{*}$ of staying in states of semi-Markov process and the availability of technical objects of the transport system were determined:

$$
G^{O T}=\frac{p_{12} \cdot\left(p_{34}+p_{38}+p_{39}\right) \cdot \overline{\Theta_{2}}+\overline{\Theta_{3}}+p_{34} \cdot \overline{\Theta_{4}}+p_{35} \cdot \overline{\Theta_{5}}+p_{36} \cdot p_{67} \cdot \overline{\Theta_{7}}}{\left[\left(p_{34}+p_{38}+p_{39}\right) \cdot\left(\overline{\Theta_{1}}+p_{12} \cdot \overline{\Theta_{2}}\right)\right]+\overline{\Theta_{3}}+p_{34} \cdot \overline{\Theta_{4}}+p_{35} \cdot \overline{\Theta_{5}}+\left[p_{36} \cdot\left(\overline{\Theta_{6}}+p_{67} \cdot \overline{\Theta_{7}}\right)\right]+p_{38} \cdot \overline{\Theta_{8}}+\left(p_{38}+p_{39}\right) \cdot \overline{\Theta_{9}}} \cdot
$$

For the analyzed model of transport means operation process the values of genetic algorithm input parameters and possible decisions made in decision-making process states were determined (Table 1) as well as, based on operational data, absolute values of process state duration periods were defined (Table 2).

Genetic algorithm input parameter values:

a) Length of chromosome $m=9$

b) Size of population $n=100$

c) Number of iterations $I=100$

d) Probability of chromosome selection via elitism principle $\eta=0.2$

e) Probability of hybridization occurrence $\kappa=1$

\begin{tabular}{|c|c|c|}
\hline $\begin{array}{l}\text { Process } \\
\text { state }\end{array}$ & Decision „0" - $d_{i}^{(0)}$ & Decision ${ }^{1 "}-d_{i}^{(1)}$ \\
\hline$S_{3}$ & $\begin{array}{l}\text { The route marked code } \mathrm{L} \\
\text { ("light" conditions of the delivery task) }\end{array}$ & $\begin{array}{l}\text { The route marked code } \mathrm{D} \\
\text { ("difficult" conditions of the delivery task) }\end{array}$ \\
\hline$S_{5}$ & $\begin{array}{l}\text { Treatment by a PT type B } \\
\text { (basic range) }\end{array}$ & $\begin{array}{l}\text { Treatment by a PT type E } \\
\text { (extended range) }\end{array}$ \\
\hline
\end{tabular}

f) Probability of mutation occurrence $\mu=0.05$

Table. 1. The control decisions in the states of the analyzed operation process 
Table. 1. The control decisions in the states of the analyzed operation process (cont.)

\begin{tabular}{|c|c|c|}
\hline$S_{6}$ & $\begin{array}{l}\text { Treatment by a PT type B } \\
\text { (basic range) }\end{array}$ & $\begin{array}{l}\text { Treatment by a PT type E } \\
\text { (extended range) }\end{array}$ \\
\hline$S_{8}$ & $\begin{array}{c}\text { Treatment in positions PZZ type } \mathrm{N} \\
\text { (normal) }\end{array}$ & $\begin{array}{l}\text { Treatment in positions PZZ type I } \\
\text { (intensive) }\end{array}$ \\
\hline$S_{g}$ & $\begin{array}{l}\text { Operate in positions OC type } \mathrm{N} \\
\text { (normal) }\end{array}$ & $\begin{array}{l}\text { Operate in positions OC type I } \\
\text { (intensive) }\end{array}$ \\
\hline
\end{tabular}

Table. 2. Code markings of decisions and absolute process state duration periods

\begin{tabular}{|c|c|c|c|c|}
\hline Process state & $\boldsymbol{d}_{i}^{(0)}$ & $\boldsymbol{d}_{i}^{(1)}$ & $\boldsymbol{\Theta}_{i}^{(0)]}[\mathrm{h}]$ & $\boldsymbol{\Theta}_{i}^{(0)]}[\mathrm{h}]$ \\
\hline$S_{1}$ & 0 & 1 & 0.096 & 0.096 \\
\hline$S_{2}$ & 0 & 1 & 5.659 & 5.659 \\
\hline$S_{3}$ & 0 & 1 & 8.852 & 7.967 \\
\hline$S_{4}$ & 0 & 1 & 3.450 & 3.450 \\
\hline$S_{5}$ & 0 & 1 & 0.070 & 0.063 \\
\hline$S_{6}$ & 0 & 1 & 0.545 & 0.436 \\
\hline$S_{7}$ & 0 & 1 & 0.442 & 0.442 \\
\hline$S_{8}$ & 0 & 1 & 3.744 & 2.995 \\
\hline$S_{9}$ & 0 & 1 & 0.122 & 0.092 \\
\hline
\end{tabular}

Next, calculations were made with the help of developed computer software, implemented genetic algorithm, written at: $R$ Development Core Team (2011). $R$ : A language and environment for statistical computing. $R$ Foundation for Statistical Computing, Vienna, Austria. ISBN 3-900051-07-0. As a result of the calculations performed, for the adopted criterion (11) the optimal operation process control strategy was determined in the tested system of transport means operation - city bus operation system. Calculation results were presented in Table 3.

Table. 3. Optimal transport means operation process control strategy and criterion function value, determined on the basis of genetic algorithm (for hypothetical operational data)

\begin{tabular}{|c|c|}
\hline Optimal strategy $\delta^{*}$ & $G^{O T}\left(\delta^{*}\right)$ \\
\hline$[1,1,1,0,0,1,0,0,1]$ & 0.8426 \\
\hline
\end{tabular}




\section{Summary}

The presented method determining the optimal strategy controlling, means determination a sequence of control decisions made in individual states of the model process, for which the function constituting the criterion of evaluation achieves an extreme value. In order to specify the optimal strategy controlling the operation process of the technical objects the genetic algorithm was recommended. Due to the general character the presented method canoe implemented for solving a broad spectrum of optimization issues concerning the exploitation systems for the technical objects such as: controlling availability and reliability, analysis of costs and profits, analysis of risk and safety etc.. In each case there is a necessity to form properly the definition of the criterion and specifying possible control decisions made in the states of the examined operation process of the technical objects.

The method of determining optimal technical object operation process control strategy with the use of genetic algorithm presented in the article, constitutes one of the stages of work the goal of which is developing a complex method of technical object operation process control with the use of decision-making models. A complex method of transport means operation process control is supposed to make it possible to control both the processes carried out at the executive subsystem (evaluation of transport means tasks carried out) as well as at the serviceability assurance subsystem (evaluation of service and repair tasks carried out), taking into consideration both the technical and economic criteria of the functioning of this type of operation systems.

\section{References}

[1] DAVIS, L.D.: Handbook of genetic algorithms. Van Nostrand Reinhold 1991.

[2] GRABSKI, F., JAŹWIŃSKI, J.: Funkcje olosowych argumentach w zagadnieniach niezawodności, bezpieczeństwa i logistyki. WKit. Warszawa 2009.

[3] GOLDBERG, D. E.: Algorytmy genetyczne i ich zastosowanie. WNT. Warszawa 2003.

[4] JAŻWIŃSKI, J., GRABSKI, F.: Niektóre problemy modelowania systemów transportowych. Instytut Technologii Eksploatacji. Warszawa-Radom 2003.

[5] KOROLUK, V. S.: Modele stochastyczne systemów. Naukova Dumka. Kiev 1989.

[6] KOROLUK, V. S., TURBIN, A. F.: Semi-Markov processes and their application. Naukova Dumka. Kiev 1976.

[7] KOWALENKO, I. N., KUZNIECOW, N. J., SZURIENKOW, W. M.: Procesy stochastyczne. Poradnik. PWN. Warszawa 1989.

[8] KULKARNI, V. G.: Modeling and analysis of stochastic systems. Chapman \& Hall. New York 1995.

[9] KUSIAK, J., DANIELEWSKA-TULECKA, A., OPROCHA, P.: Optymalizacja. Wybrane metody z przykładami zastosowań. PWN. Warszawa 2009.

[10] MICHAELEWICZ, Z.: Genetic algorithms + data structure = evolution programs. Springer Verlag. Berlin 1996.

[11] MIGAWA, K.: Semi-Markov model of the availability of the means of municipal transport system. Zagadnienia Eksploatacji Maszyn, 3(159), vol. 44, Radom 2009.

[12] MIGAWA, K.: Method for control of technical objects operation process with the use of semi-Markov decision processes. Journal of KONES Powertrain and Transport, vol. 19, no. 4, 2012.

[13] MITCHELL, M.: An introduction to genetic algorithms. MIT Press. Cambridge 1996.

[14] VOSE, M.D.: The simple genetic algorithm. Foundations and theory. MIT Press. Cambridge 1998. 


\title{
ZASTOSOWANIE ALGORYTMU GENETYCZNEGO DO WYZNACZANIA OPTYMALNYCH DECYZJI STERUJĄCYCH
}

\author{
KLAUDIUSZ MIGAWA' \\ Uniwersytet Technologiczno-Przyrodniczy w Bydgoszczy
}

\section{Streszczenie}

Zagadnienia przedstawione $\mathrm{w}$ artykule dotyczą problematyki sterowania procesem eksploatacji realizowanym w złożonych systemach eksploatacji obiektów technicznych. Podejmowanie odpowiednich decyzji sterujących wpływa bezpośrednio na możliwość prawidłowej i efektywnej realizacji zadań przydzielonych systemowi. W pracy przedstawiono metodę wyznaczania optymalnej strategii sterowania procesem eksploatacji obiektów technicznych na podstawie algorytmu genetycznego. W prezentowanej metodzie wyznaczenie optymalnej strategii sterowania procesem eksploatacji obiektów technicznych dotyczy wyboru ciągu decyzji sterujących, podejmowanych w poszczególnych stanach modelowanego procesu eksploatacji. Metoda ta polega na wyborze spośród możliwych wariantów decyzyjnych, najlepszej strategii sterowania procesem eksploatacji, dla której funkcja stanowiąca kryterium oceny osiąga wartość ekstremalną. W zależności od potrzeb algorytm genetyczny wraz z opracowanym modelem procesu eksploatacji, może być zastosowany do matematycznego formułowania i rozwiązywania szerokiej gamy problemów związanych ze sterowaniem złożonymi systemami eksploatacji obiektów technicznych. Dotyczy to przede wszystkim analizy ekonomicznej, zarządzania ryzykiem i bezpieczeństwem działania złożonych systemów technicznych, a także sterowania gotowością i niezawodnością eksploatowanych obiektów technicznych. W pracy przedstawiono przykład wyznaczenia optymalnej strategii sterowania (ciągu decyzji), w przypadku, gdy funkcję kryterialną stanowi gotowość środków transportu użytkowanych w wybranym systemie eksploatacji.

Słowa kluczowe: proces eksploatacji, decyzje sterujące, algorytm genetyczny

\section{Wprowadzenie}

Prawidłowe i efektywne funkcjonowanie złożonych systemów eksploatacji obiektów technicznych, jest możliwe jedynie wówczas, gdy decyzje sterujące podejmowane przez decydentów systemu są racjonalne. W systemach, w których realizowany jest złożony proces eksploatacji obiektów technicznych, wybór racjonalnych decyzji sterujących, spośród możliwych wariantów 
decyzyjnych, jest zagadnieniem trudnym i skomplikowanym. W rzeczywistych złożonych systemach eksploatacji obiektów technicznych, proces podejmowania decyzji sterujących powinien być realizowany z zastosowaniem odpowiednich metod i narzędzi matematycznych, a nie w sposób „intuicyjny", oparty wyłącznie na wiedzy i doświadczeniu decydentów systemu. Zastosowanie odpowiednich metod matematycznych do sterowania procesem eksploatacji ułatwia wybór racjonalnych decyzji sterujących, w sposób zapewniający prawidłową i efektywną realizację zadań przydzielonych systemowi.

W przypadku złożonych systemów eksploatacji obiektów technicznych, w celu wyznaczenia optymalnej strategii sterowania procesem eksploatacji, konieczne jest zastosowanie odpowiednich i efektywnych metod i narzędzi matematycznych. W pracy jako przykładowe narzędzie wspomagające proces wyznaczania optymalnej strategii sterowania, przedstawiono algorytm genetyczny.

W literaturze przedmiotu można znaleźć wiele opracowań dotyczących zarówno teoretycznego opisu, jak i przykłady praktycznych zastosowań algorytmu genetycznego do poszukiwania rozwiązania optymalnego, np.: $[1,3,9,10,12,13,14]$. Algorytm genetyczny należy do grupy metod niedeterministycznych wyznaczania rozwiązania optymalnego, w których kolejne rozwiązania są losowymi modyfikacjami rozwiązań poprzednich i w sposób istotny od nich zależą. Podstawowym założeniem stosowania algorytmu genetycznego do poszukiwania rozwiązania optymalnego jest fakt zaczerpnięty z teorii ewolucji, że największe prawdopodobieństwo modyfikacji dotyczy rozwiązań o najwyższym stopniu przystosowania, określanym wartością funkcji przystosowania (funkcji celu zadania optymalizacyjnego).

Algorytm genetyczny może stanowić dogodne narzędzie, którego zastosowanie ułatwia skomplikowany proces podejmowania racjonalnych decyzji sterujących w złożonych systemach eksploatacji obiektów technicznych.

\section{Opis działania algorytmu genetycznego}

Do opisu działania algorytmu genetycznego przedstawionego w artykule, wykorzystano terminologię ogólnie stosowaną w literaturze przedmiotu z jednoczesnym odniesieniem do nazw i pojęć dotyczących wyznaczania optymalnej strategii sterowania procesem eksploatacji obiektów technicznych:

- gen (decyzja) - pojedynczy element chromosomu - w przypadku poszukiwania strategii optymalnej określony przez konkretną decyzję podejmowaną w danym stanie decyzyjnym rozpatrywanego procesu eksploatacji;

- chromosom (strategia) - obiekt reprezentujący istotne zmienne w procesie poszukiwania rozwiązania optymalnego (np. strategii optymalnej). Składa się z uporządkowanego ciągu genów (decyzji) o ustalonej długości (liczbie genów) i stanowi zakodowaną postać możliwych rozwiązań (strategii dopuszczalnych);

- populacja - zbiór chromosomów (zbiór strategii). Liczebność populacji jest z góry ustaIona i pozostaje stała podczas całej procedury obliczeń. W trakcie działania algorytmu 
genetycznego elementy populacji (chromosomy) podlegają modyfikacji zgodnie z przyjętym z góry schematem, w taki sposób, że po modyfikacji zachowują pewne cechy elementów (chromosomów) z wcześniejszej populacji oraz w wyniku działania czynnika losowego nabywają nowych cech;

- funkcja przystosowania - funkcja celu lub funkcja powiązana z funkcją celu w procesie poszukiwania rozwiązania optymalnego (strategii optymalnej). Umożliwia liczbową ocenę przystosowania poszczególnych chromosomów (strategii).

Na rysunku 1 przedstawiono ogólny schemat działania algorytmu genetycznego, w przypadku wyznaczania optymalnej strategii $\delta^{*}$ sterowania procesem eksploatacji obiektów technicznych.

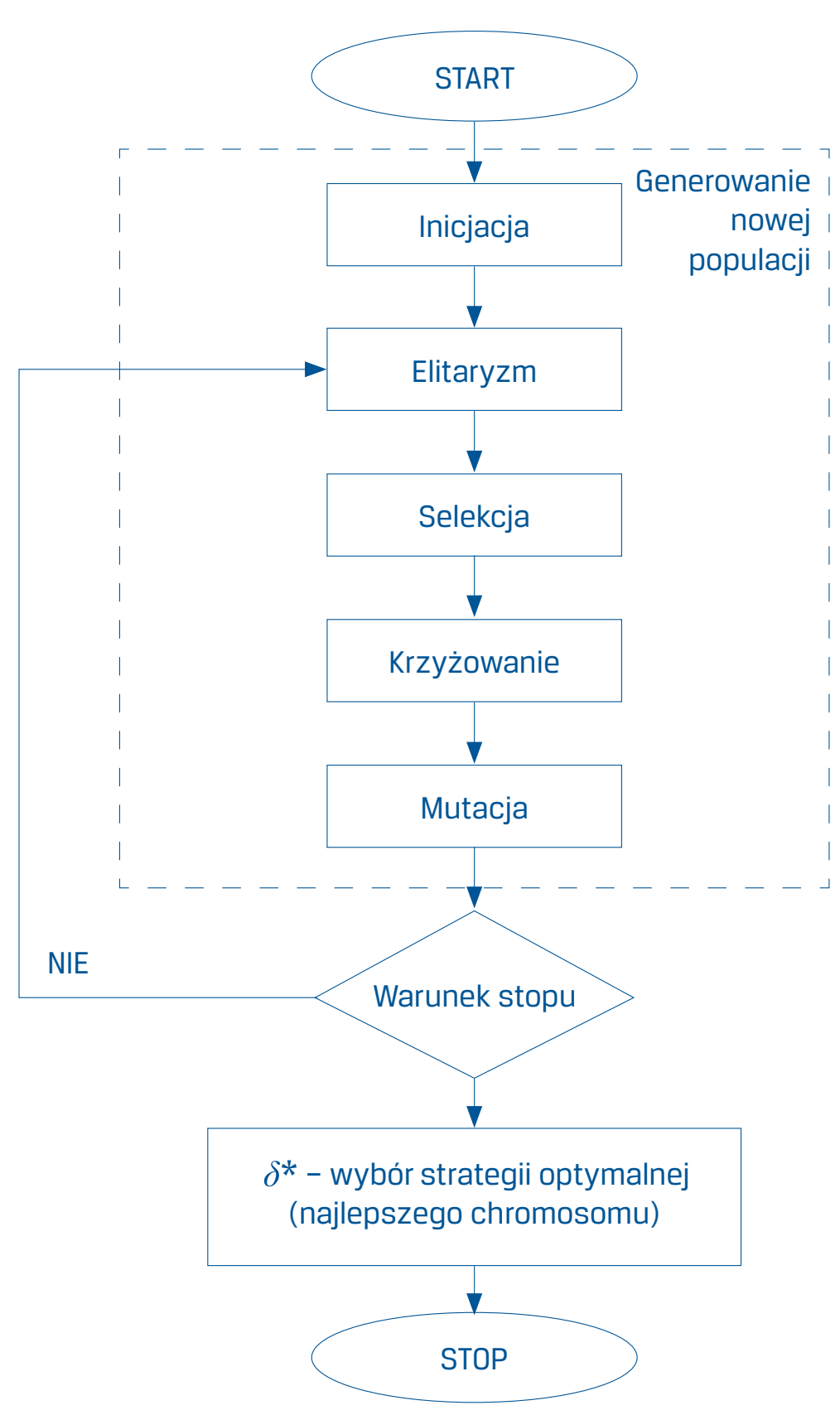

Rys. 1. Schemat działania algorytmu genetycznego - wyznaczania optymalnej strategii $\delta$ * 
Poniżej przedstawiono kolejne etapy realizacji algorytmu genetycznego:

\section{Etap I - INICJACJA}

Inicjacja jest etapem wstępnym realizacji algorytmu genetycznego. W trakcie realizacji tego etapu dokonywane jest ustalenie podstawowych parametrów algorytmu, zasad kodowania zmiennych optymalizacji, wyznaczenie populacji początkowej, określenie funkcji przystosowania oraz wyznaczenie wartości funkcji przystosowania dla poszczególnych chromosomów (strategii $\delta$ ) populacji początkowej.

\section{Etap I.a - Ustalenie podstawowych parametrów algorytmu genetycznego}

Podstawowymi parametrami algorytmu genetycznego są:

- długość $m$ chromosomu, wyznaczona przez liczbę genów w chromosomie. Liczba genów w chromosomie jest równa liczbie rozpatrywanych, istotnych zmiennych w danym zadaniu optymalizacji;

- liczebność $n$ populacji, czyli liczba chromosomów w populacji. Ze względu na dokładność i wiarygodność wyników, bardzo istotnym problemem jest odpowiedni dobór liczby chromosomów w populacji. Liczba chromosomów w populacji nie powinna być zbyt mała, gdyż ogranicza to możliwość ewolucji populacji, a w wyniku tego zostaje zawężony rozpatrywany (przeszukiwany) podzbiór rozwiązań w kolejnych iteracjach (dla kolejnych populacji). Z drugiej strony bardzo liczna populacja może powodować znaczące wydłużenie czasu obliczeń w kolejnych iteracjach. Liczba chromosomów w populacji zależy zarówno od długości chromosomu oraz od zastosowanej metody kodowania;

- współczynnik $\eta$ - określający prawdopodobieństwo doboru chromosomów na zasadzie elitaryzmu. Zasada elitaryzmu dotyczy wyboru najlepiej przystosowanych chromosomów należących do populacji poprzedniej i skopiowaniu ich do nowej populacji. W zależności od wielkości tworzonej nowej populacji kopiowany jest jeden lub kilka najlepiej przystosowanych chromosomów z populacji poprzedniej;

- współczynnik $\kappa$ - określający prawdopodobieństwo zajścia krzyżowania. Krzyżowanie polega na wymianie genów pomiędzy chromosomami pochodzącymi od poszczególnych par rodzicielskich. W efekcie realizacji operacji krzyżowania zostają utworzone chromosomy potomków, będące pewnymi kombinacjami genów odpowiednich par chromosomów rodzicielskich;

- współczynnik $\mu$ - określający prawdopodobieństwo zajścia mutacji. Mutacja jest ostatnim etapem generowania chromosomów nowej populacji i dotyczy zmiany poszczególnych genów chromosomu potomka utworzonego na etapie krzyżowania w sposób całkowicie losowy. 


\section{Etap I.b - Ustalenie zasad kodowania zmiennych optymalizacji}

W przypadku wyboru metody kodowania, należy mieć na uwadze kilka podstawowych zasadach:

- stosując wybraną metodę kodowania, należy uwzględnić fakt, że umożliwia ona jedynie kodowanie skończonej liczby elementów ze zbioru rozwiązań dopuszczalnych. Oznacza to, że należy tak dobrać metodę kodowania, aby w danym zadaniu optymalizacji, zapewnić możliwość zakodowania rozpatrywanego zbioru rozwiązań dopuszczalnych (chromosomów), określonego przez liczbę możliwych chromosomów oraz ich długość (liczbę genów w chromosomie);

- wybrana metoda musi w sposób jednoznaczny umożliwiać identyfikację poszczególnych elementów zbioru rozwiązań dopuszczalnych (chromosomów);

- wybrana metoda powinna eliminować możliwość utworzenia, w wyniku działania algorytmu genetycznego, chromosomu nie mającego odpowiednika w zbiorze rozwiązań dopuszczalnych.

W przypadku stosowania algorytmu genetycznego, spośród wielu metod kodowania zmiennych optymalizacji, najczęściej stosowane jest kodowanie binarne. Metoda kodowania binarnego umożliwia zakodowanie poszczególnych elementów zbioru rozwiązań dopuszczalnych (chromosomów), w taki sposób, że liczba genów w chromosomie równa jest liczbie rozpatrywanych, istotnych zmiennych optymalizacji. W przypadku zastosowania metody kodowania binarnego, ustalenie liczby genów $m$ chromosomu, w sposób jednoznaczny określa maksymalną liczbę chromosomów w zbiorze rozwiązań dopuszczalnych, która wynosi $2^{m}$.

\section{Etap I.c - Wyznaczenie populacji początkowej (startowej)}

Po ustaleniu podstawowych parametrów optymalizacji oraz zasad kodowania, za pomocą metody losowej generowana jest populacja początkowa $\Delta^{(0)}$ o liczności $n$ elementów (chromosomów), w postaci następującego ciągu

$$
\Delta^{(0)}=\left\{\delta_{1}^{(0)}, \delta_{2}^{(0)}, \ldots, \delta_{n-1}^{(0)}, \delta_{n}^{(0)}\right\} .
$$

Kolejność wylosowanych elementów (chromosomów) w populacji jest dowolna oraz istnieje możliwość wielokrotnego pojawienia się w danej populacji tych samych elementów (chromosomów).

\section{Etap I.d - Wyznaczenie wartości funkcji przystosowania dla populacji początkowej}

Optymalizacja danego zadania z zastosowaniem algorytmu genetycznego jest możliwa jedynie wówczas, gdy dysponujemy tzw. funkcją przystosowania, dla której możliwe jest 
znalezienie wartości maksymalnej lub minimalnej (w zależności od rozpatrywanego zadania optymalizacji). Funkcją przystosowania może być zarówno funkcja celu, jak i każda funkcja ściśle powiązana z funkcją celu rozważanego zadania optymalizacji. Wyznaczenie wartości funkcji przystosowania umożliwia liczbową ocenę przystosowania poszczególnych chromosomów w analizowanej populacji.

Jeżeli w danym zadaniu optymalizacji:

- funkcja celu $f_{C}$ określona jest na zbiorze $X$, czyli $f_{C}: X \rightarrow R$,

- $\delta(x)$ oznacza chromosom identyfikujący w sposób jednoznaczny element $x \in X$,

- określony jest zbiór rozwiązań dopuszczalnych $Y$ będący podzbiorem zbioru $X$.

Wówczas funkcja $f_{P}: \Delta \rightarrow R$ jest funkcją przystosowania rozpatrywanego zadania optymalizacji, gdzie $\Delta$ oznacza zbiór chromosomów o długości $m$, złożonych z binarnych genów $d_{j} \in\{0,1\}, j=1,2, \ldots, m$, określony następująco:

$$
\Delta=\{\delta(x): x \in Y\},
$$

gdzie:

$$
\delta(x)=\left[d_{1}, d_{2}, \ldots, d_{m}\right]: d_{j} \in\{0,1\}, j=1,2, \ldots, m .
$$

Tak określona funkcja przystosowania $f_{P}: \Delta \rightarrow R$ może być odpowiednikiem funkcji celu $f_{C}: X \rightarrow R$ w następującej formie:

- w przypadku maksymalizacji funkcji celu:

$$
f_{P}(\delta(x))=f_{C}(x),
$$

- w przypadku minimalizacji funkcji celu:

$$
f_{P}(\delta(x))=-f_{C}(x) \text {. }
$$

Wartość funkcji przystosowania $f_{P}(\delta(x))$ można wyznaczyć wówczas, gdy znana jest relacja pomiędzy zbiorem chromosomów $\Delta$ i zbiorem rozwiązań dopuszczalnych $Y$ oraz związek funkcji przystosowania $f_{P}(\delta(x))$ i funkcji celu $f_{C}(x)$. 


\section{Etap II - GENEROWANIE POPULACJI W KOLEJNYCH ITERACJACH}

Podstawowym założeniem w metodzie optymalizacji z zastosowaniem algorytmu genetycznego jest to, aby populacje chromosomów wygenerowane w kolejnych iteracjach, były lepiej przystosowane niż populacje chromosomów wygenerowane w iteracjach poprzednich. Oznacza to, że wyznaczone wartości funkcji przystosowania $f_{P}(\delta(x))$, dla kolejno wygenerowanych populacji chromosomów, są coraz większe w przypadku poszukiwania maksimum lub coraz mniejsze w przypadku poszukiwania minimum.

Wynikiem realizacji tego etapu jest generowanie elementów (chromosomów) nowych populacji $\Delta^{(I)}$ (powstałych w kolejnych iteracjach $I$ ) z elementów (chromosomów) poprzednich populacji $\Delta^{(I-1)}$. Sposób generowania elementów nowej populacji polega na $n$ krotnym wylosowaniu $n$ par chromosomów, tzw. par rodzicielskich, a następnie utworzeniu $n$ potomków nowej populacji, w wyniku $n$ krotnego zastosowania kolejno operacje: selekcji, krzyżowania i mutacji. W wyniku operacji krzyżowania i mutacji, wyselekcjonowane chromosomy poddawane są losowym modyfikacjom, co może powodować ryzyko utracenia najlepiej przystosowanego chromosomu z populacji poprzedniej. $Z$ tego powodu, w praktyce stosowana jest często tzw. zasada elitaryzmu.

\section{Etap II.a - Elitaryzm}

Zgodnie z zasadą elitaryzmu przynajmniej jeden spośród najlepiej przystosowanych chromosomów jest kopiowany do nowej populacji. W przypadku stosowania algorytmu genetycznego, dla zapewnienia coraz lepszego przystosowania kolejnych populacji, zakłada się, że największy wpływ na nową populacje powinny mieć elementy (chromosomy) należące do populacji poprzedniej, dla których funkcja przystosowania przyjmowała największe wartości. Zgodnie z tym założeniem chromosomy słabo przystosowane nie powinny trafić do nowo tworzonej populacji.

Zasada elitaryzmu dotyczy wyboru najlepszych (najlepiej przystosowanych) elementów (chromosomów) z spośród elementów (chromosomów) populacji poprzedniej i skopiowaniu ich do nowej populacji. Liczba kopiowanych chromosomów może być różna. Najczęściej przyjmuje się, że kopiowany jest jeden lub kilka najlepiej przystosowanych chromosomów z populacji poprzedniej. Zasada elitaryzmu umożliwia lepsze funkcjonowanie algorytmu genetycznego i polega na tym, że najlepszy wynik (najlepiej przystosowany chromosom) jest pamiętany (kopiowany do kolejnych populacji) tak długo, aż nastąpi znalezienie lepszego rozwiązania - chromosomu, dla którego wartość funkcji przystosowania jest wyższa.

Często do wyboru elementów, które będą kopiowane do nowej populacji stosuje się metody losowe. Wówczas wyznacza się wartość współczynnika $\eta$ określającego prawdopodobieństwo doboru chromosomów na zasadzie elitaryzmu. Oznacza to, że chromosomy mające trafić do nowej populacji, dobierane są na zasadzie elitaryzmu z prawdopodobieństwem $\eta$, a dobierane na zasadzie selekcji, krzyżowania i mutacji z prawdopodobieństwem $1-\eta$. 


\section{Etap II.b - Selekcja}

Celem etapu selekcji jest wybór spośród chromosomów populacji poprzedniej, tych chromosomów, które na etapie krzyżowania będą tworzyć tzw. pary chromosomów rodzicielskich. Selekcja chromosomów jest procesem losowym, w którym na wybór do pary rodzicielskiej istotny wpływ powinno mieć posiadanie przez dany chromosom pożądanych cech (wartości funkcji przystosowania). Oznacza to, że jeżeli danemu chromosomowi przypisana jest lepsza (odpowiednio większa lub mniejsza) wartość funkcji przystosowania, tym większe powinno być prawdopodobieństwo wylosowania tego chromosomu do pary rodzicielskiej. Jedną z najprostszych i najczęściej stosowanych na etapie selekcji metod losowania jest tzw. metoda koła ruletki, w której spełniony jest warunek proporcjonalności szansy wylosowania danego chromosomu do wyznaczonej dla niego wartości funkcji przystosowania.

\section{Etap II.c - Krzyżowanie}

Celem operacji krzyżowania jest przekazanie cech poszczególnych par chromosomów rodzicielskich (dobranych na etapie selekcji), nowo utworzonym na etapie krzyżowania chromosomom potomstwa. Operacja krzyżowania polega na wymianie, za pomocą określonego operatora krzyżowania, genów pomiędzy chromosomami pochodzącymi od poszczególnych par rodzicielskich. W efekcie realizacji operacji krzyżowania zostają utworzone chromosomy potomków, będące pewnymi kombinacjami genów odpowiednich par chromosomów rodzicielskich.

W celu stwierdzenia czy operacja krzyżowania będzie zastosowana, przyjmuje się wartość współczynnika $\kappa \in\langle 0,1\rangle$, określającego prawdopodobieństwo zajścia krzyżowania. Następnie dla każdej z par chromosomów rodzicielskich (z populacji wcześniejszej) losuje się liczbę $x \in\langle 0,1\rangle$. Operacja krzyżowania, dla danej pary chromosomów rodzicielskich, jest realizowana wówczas, gdy wartość wylosowanej liczby $x<\kappa$. Natomiast w przypadku, gdy $x \geq \kappa$ krzyżowanie nie jest realizowane i do populacji następnej kopiowany jest jeden z chromosomów rodzicielskich (wybrany w wyniku losowania). Należy zauważyć, że dla $\kappa=0$ krzyżowanie nigdy nie jest realizowane, a dla $\kappa=1$ jest realizowane bardzo często (krzyżowanie zostanie zrealizowane dla większości par chromosomów rodzicielskich).

Właściwy dobór metody krzyżowania wpływa na poprawność działania algorytmu genetycznego. Niestety nie istnieje jeden najlepszy sposób krzyżowania chromosomów, a skuteczność jego doboru zależy od analizowanej funkcji celu danego zadania optymalizacji. Opracowano wiele metod krzyżowania, stosowanych w optymalizacji z wykorzystaniem algorytmu genetycznego. Wśród wielu dostępnych operatorów krzyżowania, najczęściej stosowanymi w praktyce są:

- operator krzyżowania jednopunktowego,

- operator krzyżowania dwupunktowego,

- operator krzyżowania jednorodnego,

- operator krzyżowania AND,

- operator krzyżowania XOR, 
- operator krzyżowania BLX- $\alpha$,

- operator krzyżowania MIN-MAX,

- operator krzyżowania FCB.

\section{Etap II.d - Mutacja}

Mutacja jest ostatnim etapem generowania elementów (chromosomów) nowej populacji i dotyczy zmiany poszczególnych genów chromosomu potomka uprzednio utworzonego na etapie krzyżowania. Zastosowanie mutacji umożliwia zaliczenie do elementów nowej populacji także tych chromosomów, które z założenia są praktycznie niemożliwe do uzyskania w wyniku samego krzyżowania (z elementów populacji poprzedniej).

Na etapie mutacji zmiany poszczególnych genów realizowane są w sposób całkowicie losowy. Wartości prawdopodobieństwa zajścia mutacji dla poszczególnych genów chromosomu, ustalane są na etapie inicjacji algorytmu genetycznego. W celu stwierdzenia czy operacja mutacji będzie zastosowana, przyjmuje się wartość współczynnika $\mu \in\langle 0,1\rangle$, określającego prawdopodobieństwo zajścia mutacji. Następnie dla każdego genu $d_{j}$ analizowanego chromosomu (utworzonego na etapie krzyżowania) losuje się liczbę $x_{j} \in\langle 0,1\rangle$. Mutacja genu $d_{j}$ jest realizowana wówczas, gdy wartość wylosowanej liczby $x_{j}<\mu$. Natomiast w przypadku, gdy $x_{j} \geq \mu$ mutacja genu $d_{j}$ nie jest realizowana. Należy zauważyć, że dla $\mu=0$ krzyżowanie nigdy nie jest realizowane, a dla $\mu=1$ jest realizowane bardzo często (mutacja zostanie zrealizowana dla większości genów).

\section{Etap III - WARUNEK STOPU}

W przypadku wyboru strategii optymalnej (najlepszego chromosomu) na podstawie algorytmu genetycznego, możliwe jest zastosowanie dwóch warunków stopu:

- osiągnięcie założonej liczby iteracji,

- niewielkie zmiany wartości funkcji celu (funkcji przystosowania) wyznaczone dla strategii (chromosomu) najlepiej przystosowanej spośród elementów badanych populacji, podczas kilku kolejnych iteracji.

\section{Wybór optymalnej strategii sterowania procesem eksploatacji obiektów technicznych}

Ze względu na losowy charakter czynników wpływających na przebieg procesu eksploatacji obiektów technicznych (np. środków transportu), najczęściej do matematycznego modelowania procesu eksploatacji wykorzystywane są procesy stochastyczne. Spośród procesów losowych szerokie zastosowanie w modelowaniu procesu eksploatacji obiektów technicznych znalazły procesy Markowa i semi-Markowa, natomiast w przypadku zagadnień dotyczących sterowania złożonymi procesami eksploatacji - decyzyjne procesy Markowa oraz semi-Markowa $[2,4,5,6,7,8,11]$. 
Zakładając, że analizowany model procesu eksploatacji obiektów technicznych jest procesem stochastycznym $\{X(t): t \geq 0\}$ o skończonej liczbie stanów procesu $i=1,2, \ldots, m$, wówczas:

$$
D_{i}=\left\{d_{i}^{(1)}\left(t_{n}\right), d_{i}^{(2)}\left(t_{n}\right), \ldots, d_{i}^{(k)}\left(t_{n}\right)\right\},
$$

oznacza zbiór wszystkich możliwych decyzji, które można zastosować w i-tym stanie procesu, w chwili $t_{n^{\prime}}$ gdzie $d_{i}^{(k)}\left(t_{n}\right)$ oznacza $k$-tą decyzję sterującą podejmowaną w $i$-tym stanie procesu, w chwili $t_{n}$.

W przypadku, gdy zadanie optymalizacyjne polega na wyborze optymalnej strategii sterowania procesem eksploatacji obiektów technicznych spośród strategii dopuszczalnych, wówczas jako strategię $\delta$ rozumie się ciąg, którego wyrazami są wektory, złożone z decyzji $d_{i}^{(k)}\left(t_{n}\right)$ podejmowanych w kolejnych chwilach $t_{n}$ zmian stanów modelowanego procesu eksploatacji obiektów technicznych:

$$
\left.\delta=\left\{d_{1}^{(k)}\left(t_{n}\right), d_{2}^{(k)}\left(t_{n}\right), \ldots, d_{m}^{(k)}\left(t_{n}\right)\right]: \quad n=0,1,2, \ldots\right\} .
$$

Wybór właściwej strategii sterowania $\delta$ nazywanej strategią optymalną $\delta^{*}$, dotyczy sytuacji, gdy funkcja stanowiąca kryterium wyboru strategii optymalnej przyjmuje wartość ekstremalną (minimalną lub maksymalną).

W celu wyznaczenia optymalnej strategii sterowania (ciągu decyzji) możliwe jest zastosowanie decyzyjnych procesów semi-Markowa. Decyzyjny proces semi-markowski to proces stochastyczny $X(t): t \geq 0$, którego realizacja zależy od podejmowanych decyzji w chwili początkowej procesu $t_{0}$ oraz w chwilach zmian stanów procesu $t_{1}, t_{2}, \ldots, t n, \ldots$ W przypadku stosowania decyzyjnych procesów semi-Markowa, podjęcie w chwili $t_{n^{\prime}} k$-tej decyzji sterującej $w i$-tym stanie procesu, oznacza wybór $i$-tego wiersza jądra procesu, ze zbioru:

$$
\left\{Q_{i j}^{(k)}(t): t \geq 0, \quad d_{i}^{(k)}\left(t_{n}\right) \in D_{i}, \quad i, j \in S\right\},
$$

gdzie:

$$
Q_{i j}^{(k)}(t)=p_{i j}^{(k)} \cdot F_{i j}^{(k)}(t)
$$

Wybór $i$-tego wiersza jądra procesu wyznacza probabilistyczny mechanizm ewolucji procesu w przedziale czasu $\left\langle t_{n} ; t_{n+1}\right)$. Oznacza to, że dla procesu semi-markowskiego, w przypadku zmiany stanu procesu $z$ dowolnego na $i$-ty (wejścia do $i$-tego stanu procesu) w chwili $t_{n^{\prime}}$ podejmowana jest decyzja $d_{i}^{(k)}\left(t_{n}\right) \in D_{i}$ oraz zgodnie z rozkładem $\left(p_{i j}^{(k)}: j \in S\right)$ zostaje wygenerowany $j$-ty stan procesu, do którego następuje przejście $\mathrm{w}$ chwili $t_{\mathrm{n}+1}$. Jednocześnie zgodnie z rozkładem określonym przez dystrybuantę $F_{i j}^{(k)}(t)$, zostaje 
wygenerowana długość przedziału czasu «tn; $t_{\mathrm{n}+1}$ ) pozostawania w $i$-tym stanie procesu, gdy następnym stanem jest stan $j$-ty.

W przypadku zastosowania algorytmu genetycznego, do wyznaczania strategii optymalnej $\delta^{*}$ sterowania procesem eksploatacji obiektów technicznych, należy przyjąć następujące założenia:

- badany model procesu eksploatacji obiektów technicznych jest $m$ stanowym procesem stochastycznym,

- w każdym stanie modelu procesu eksploatacji można zastosować jedną z dwóch możliwych decyzji,

- jeśli decyzje zostaną oznaczone jako 0 i 1 (kodowanie binarne), to liczba możliwych do zastosowania strategii sterowania, dla $m$ stanowego modelu procesu eksploatacji obiektów technicznych, wynosi $2^{m}$,

- zbiór strategii sterowania jest zbiorem funkcji:

$$
\delta: S \rightarrow D
$$

gdzie:

$S$ - jest zbiorem stanów modelu procesu, $S=\{1,2, \ldots, m\}$,

$D$ - jest zbiorem decyzji podejmowanych w stanach modelu procesu, $D=\{0,1\}$.

Na podstawie powyższych założeń, każdą możliwą strategię sterowania można przedstawić jako $m$ pozycyjny ciąg złożony z 0 i 1 . Jest to więc pozycyjna liczba binarna. Wówczas przykładowa strategia sterowania, dla $m=9$ stanowego modelu procesu eksploatacji, jest określona następująco: $\delta=[1,0,1,1,0,1,0,0,1]$.

\section{Przykład wyznaczenia optymalnej strategii sterowania procesem eksploatacji obiektów technicznych}

Poniżej przedstawiono przykład wyznaczenia optymalnej strategii sterowania procesem eksploatacji realizowanym w wybranym systemie eksploatacji środków transportu - systemie autobusowego transportu miejskiego. W przedstawionym przykładzie kryterium wyznaczenia strategii optymalnej $\delta *$ stanowi wartość funkcji opisującej gotowość obiektu technicznego (środka transportu) $G^{O T}$. Wówczas wybór strategii optymalnej $\delta *$ dokonywany jest na podstawie następującego kryterium:

$$
G^{O T}\left(\delta^{*}\right)=\max _{\delta}\left[G^{O T}(\delta)\right] .
$$

Ocena poziomu gotowości środków transportu może być dokonana na podstawie matematycznego modelu procesu eksploatacji, realizowanego w badanym systemie eksploatacji środków transportu (autobusów miejskich). 
W wyniku identyfikacji badanego procesu eksploatacji środków transportu, wyznaczono istotne stany eksploatacyjne tego procesu oraz możliwe przejścia między wyróżnionymi stanami. Na tej podstawie zbudowano graf zmian stanów procesu eksploatacji, przedstawiony na rysunku 2.

Matematyczny model analizowanego procesu eksploatacji środków transportu został zbudowany na podstawie opracowanego modelu zdarzeniowego tego procesu, przy wykorzystaniu teorii procesów semi-Markowa. Proces semimarkowski $X(t)$ jest procesem, w którym czasy między zmianami kolejnych stanów procesu mają dowolne rozkłady prawdopodobieństwa i przejście do następnego stanu zależy tylko od aktualnego stanu procesu. Stosując do matematycznego modelowania procesu eksploatacji procesy semi-Markowa, przyjęto następujące założenia:

- modelowany proces eksploatacji posiada skończoną liczbę stanów $S_{i}, i=1,2, \ldots, 9$,

- jeśli obiekt techniczny w chwili $t$ znajduje się w stanie $S_{i^{\prime}}$ to $X(t)=i$, gdzie $i=1,2, \ldots, 9$,

- proces losowy $X(t)$ będący matematycznym modelem procesu eksploatacji jest procesem jednorodnym,

- w chwili $t=0$ proces znajduje się w stanie $S_{3}$ (stanem początkowym jest stan $S_{3}$ ), tzn. $P\{X(0)=3\}=1$.

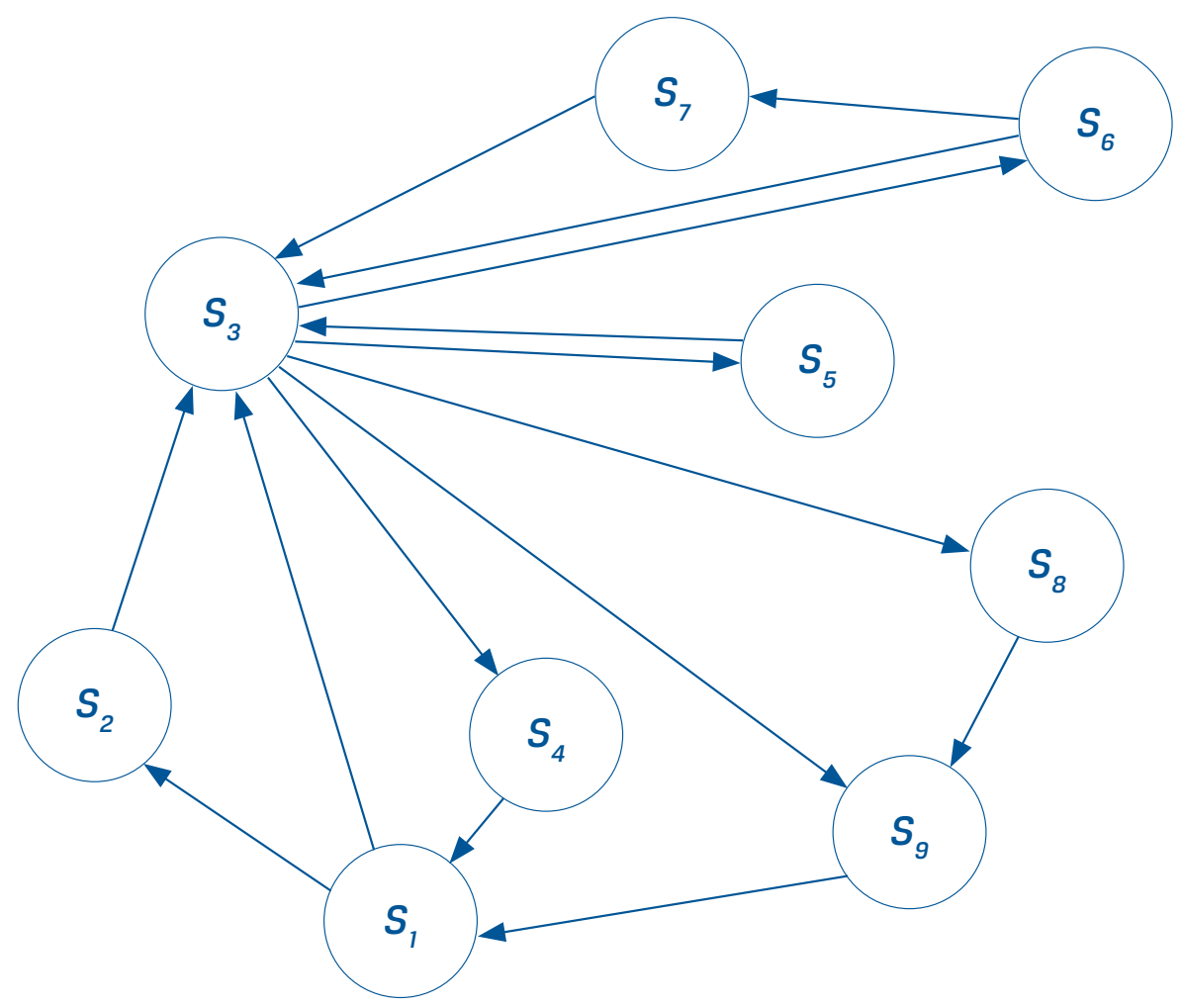

Rys. 2. Graf skierowany odwzorowania procesu eksploatacji środków transportu, gdzie:

$S_{1}$ - uzupełnianie paliwa, $S_{2}$ - postój na placu zajezdni autobusowej, $S_{3}$ - realizacja zadania przewozowego, $S_{4}$ - oczekiwanie na realizację zadania między szczytami komunikacyjnymi, $S_{5}$ - uzdatnianie przez jednostkę pogotowia technicznego bez utraty kursu, $S_{6}$ - uzdatnianie przez jednostkę pogotowia technicznego $z$ utratą kursu, $S_{7}$ - oczekiwanie na realizację zadania po uzdatnianiu przez pogotowie techniczne, $S_{8}$ - uzdatnianie na stanowiskach podsystemu zapewniania zdatności, $S_{9}$ - realizacja obsługi w dniu użytkowania 
Jednorodny proces semimarkowski jest jednoznacznie określony, gdy dany jest rozkład początkowy procesu oraz jego jądro. Z przyjętych założeń oraz na podstawie grafu skierowanego przedstawionego na rysunku 2 , rozkład początkowy $p_{i}(0), i=1,2, \ldots, 9$ ma postać:

$$
p_{i}(0)=\left\{\begin{array}{lll}
1 & g d y & i=3 \\
0 & g d y & i \neq 3
\end{array},\right.
$$

gdzie:

$$
p_{i}(0)=P\{X(0)=i\}, \quad i=1,2, \ldots, 9 ;
$$

natomiast jądro procesu $Q(t)$ ma postać:

$$
Q(t)=\left[\begin{array}{ccccccccc}
0 & Q_{12}(t) & Q_{13}(t) & 0 & 0 & 0 & 0 & 0 & 0 \\
0 & 0 & Q_{23}(t) & 0 & 0 & 0 & 0 & 0 & 0 \\
0 & 0 & 0 & Q_{34}(t) & Q_{35}(t) & Q_{36}(t) & 0 & Q_{38}(t) & Q_{39}(t) \\
Q_{41}(t) & 0 & 0 & 0 & 0 & 0 & 0 & 0 & 0 \\
0 & 0 & Q_{53}(t) & 0 & 0 & 0 & 0 & 0 & 0 \\
0 & 0 & Q_{63}(t) & 0 & 0 & 0 & Q_{67}(t) & 0 & 0 \\
0 & 0 & Q_{73}(t) & 0 & 0 & 0 & 0 & 0 & 0 \\
0 & 0 & 0 & 0 & 0 & 0 & 0 & 0 & Q_{89}(t) \\
Q_{91}(t) & 0 & 0 & 0 & 0 & 0 & 0 & 0 & 0
\end{array}\right]
$$

gdzie:

$$
\begin{gathered}
Q_{i j}(t)=P\left\{X\left(\tau_{n+1}\right)=j, \tau_{n+1}-\tau_{n} \leq t \mid X\left(\tau_{n}\right)=i\right\}, i, j=1,2, \ldots, 9, \\
Q_{i j}(t)=p_{i j} \cdot F_{i j}(t), \\
p_{i j}(t)=P\{X(t)=j \mid X(0)=i\}
\end{gathered}
$$

jest prawdopodobieństwem warunkowym przejścia ze stanu $S_{i}$ do stanu $S_{j^{\prime}}$

$$
F_{i j}(t)=P\left\{\tau_{n+1}-\tau_{n} \leq t \mid X\left(\tau_{n}\right)=i, X\left(\tau_{n+1}\right)=j\right\}, i, j=1,2, \ldots, 9
$$

jest dystrybuantą zmiennej losowej oznaczającej czas trwania stanu $S_{i^{\prime}}$ pod warunkiem, że następnym stanem będzie $\operatorname{stan} S_{j}$. 
W celu wyznaczenia wartości prawdopodobieństw granicznych $p_{i}{ }^{*}$ przebywania w stanach semimarkowskiego modelu procesu eksploatacji środków transportu zostały zbudowane: macierz $P$ prawdopodobieństw zmian stanów oraz macierz $\Theta$ warunkowych czasów trwania stanów procesu $X(t)$ :

$$
\begin{aligned}
P & =\left[\begin{array}{ccccccccc}
0 & p_{12} & p_{13} & 0 & 0 & 0 & 0 & 0 & 0 \\
0 & 0 & 1 & 0 & 0 & 0 & 0 & 0 & 0 \\
0 & 0 & 0 & p_{34} & p_{35} & p_{36} & 0 & p_{38} & p_{39} \\
1 & 0 & 0 & 0 & 0 & 0 & 0 & 0 & 0 \\
0 & 0 & 1 & 0 & 0 & 0 & 0 & 0 & 0 \\
0 & 0 & p_{63} & 0 & 0 & 0 & p_{67} & 0 & 0 \\
0 & 0 & 1 & 0 & 0 & 0 & 0 & 0 & 0 \\
0 & 0 & 0 & 0 & 0 & 0 & 0 & 0 & 1 \\
1 & 0 & 0 & 0 & 0 & 0 & 0 & 0 & 0
\end{array}\right], \\
\Theta & =\left[\begin{array}{ccccccccc}
0 & \bar{\Theta}_{12} & \bar{\Theta}_{13} & 0 & 0 & 0 & 0 & 0 & 0 \\
0 & 0 & \bar{\Theta}_{23} & 0 & 0 & 0 & 0 & 0 & 0 \\
0 & 0 & 0 & \bar{\Theta}_{34} & \bar{\Theta}_{35} & \bar{\Theta}_{36} & 0 & \bar{\Theta}_{38} & \bar{\Theta}_{39} \\
\bar{\Theta}_{41} & 0 & 0 & 0 & 0 & 0 & 0 & 0 & 0 \\
0 & 0 & \bar{\Theta}_{53} & 0 & 0 & 0 & 0 & 0 & 0 \\
0 & 0 & \bar{\Theta}_{63} & 0 & 0 & 0 & \bar{\Theta}_{67} & 0 & 0 \\
0 & 0 & \bar{\Theta}_{73} & 0 & 0 & 0 & 0 & 0 & 0 \\
0 & 0 & 0 & 0 & 0 & 0 & 0 & 0 & \bar{\Theta}_{89} \\
\bar{\Theta}_{91} & 0 & 0 & 0 & 0 & 0 & 0 & 0 & 0
\end{array}\right] .
\end{aligned}
$$

Na podstawie macierzy $P$ oraz macierzy $\Theta$, wyznaczono bezwarunkowe czasy trwania poszczególnych stanów procesu, według zależności:

$$
\overline{\Theta_{i}}=\sum_{i=1}^{9} p_{i j} \cdot \overline{\Theta_{i j}}, i, j=1,2, \ldots, 9 .
$$

Następnie, na podstawie twierdzenia granicznego dla procesów semimarkowskich [2], zostały wyznaczone prawdopodobieństwa graniczne $p_{i}{ }^{*}$ przebywania w stanach procesu:

$$
p_{i}^{*}=\lim _{t \rightarrow \infty} p_{i}(t)=\frac{\pi_{i} \cdot E\left(\Theta_{i}\right)}{\sum_{i \in S} \pi_{i} \cdot E\left(\Theta_{i}\right)},
$$

gdzie prawdopodobieństwa $\pi_{i}, i \in S$ stanowią rozkład stacjonarny włożonego w proces łańcucha Markowa, który spełnia układ równań liniowych: 


$$
\sum_{i \in S} \pi_{i} \cdot p_{i j}=\pi_{j}, \quad j \in S, \quad \sum_{i \in S} \pi_{i}=1
$$

Gotowość pojedynczego obiektu technicznego określona na podstawie semi-markowskiego modelu procesu eksploatacji, wyznaczana jest jako suma prawdopodobieństw granicznych $p_{i}{ }^{*}$ przebywania w stanach należących do zbioru stanów gotowości:

$$
G^{O T}=\sum_{i} p_{i}^{*}, \text { dla } S_{i} \in S_{G}
$$

W celu wyznaczenia gotowości obiektów technicznych (środków transportu) na podstawie semi-markowskiego modelu procesu eksploatacji, stany analizowanego procesu należy podzielić na stany gotowości $S_{G}$ i niegotowości $S_{N G}$ do realizacji przydzielonego zadania przewozowego. W prezentowanym modelu wyróżniono następujące stany gotowości: stan $S_{2}$ - postój na placu zajezdni autobusowej, stan $S_{3}$ - realizacja zadania przewozowego, stan $S_{4}$ - oczekiwanie na realizację zadania między szczytami komunikacyjnymi, stan $S_{7}$ - oczekiwanie na realizację zadania po uzdatnianiu przez pogotowie techniczne.

Następnie przy użyciu programu MATHEMATICA, zostały wyznaczone wzory opisujące prawdopodobieństwa graniczne $p_{i}{ }^{*}$ przebywania w stanach procesu semi-Markowa oraz gotowość obiektów technicznych:

$G^{O T}=\frac{p_{12} \cdot\left(p_{34}+p_{38}+p_{39}\right) \cdot \overline{\Theta_{2}}+\overline{\Theta_{3}}+p_{34} \cdot \overline{\Theta_{4}}+p_{35} \cdot \overline{\Theta_{5}}+p_{36} \cdot p_{67} \cdot \overline{\Theta_{7}}}{\left[\left(p_{34}+p_{38}+p_{39}\right) \cdot\left(\overline{\Theta_{1}}+p_{12} \cdot \overline{\Theta_{2}}\right)\right]+\overline{\Theta_{3}}+p_{34} \cdot \overline{\Theta_{4}}+p_{35} \cdot \overline{\Theta_{5}}+\left[p_{36} \cdot\left(\overline{\Theta_{6}}+p_{67} \cdot \overline{\Theta_{7}}\right)\right]+p_{38} \cdot \overline{\Theta_{8}}+\left(p_{38}+p_{39}\right) \cdot \overline{\Theta_{9}}} \cdot$

Dla rozpatrywanego modelu procesu eksploatacji środków transportu, określono wartości parametrów wejściowych algorytmu genetycznego, możliwe decyzje podejmowane w decyzyjnych stanach procesu (Tabela 1) oraz na podstawie danych eksploatacyjnych wyznaczono wartości bezwarunkowych czasów trwania stanów procesu (Tabela 2).

Wartości parametrów wejściowych algorytmu genetycznego:

a) długość chromosomu $m=9$

b) liczebność populacji $n=100$

c) liczba iteracji $I=100$

d) prawdopodobieństwo doboru chromosomów na zasadzie elitaryzmu $\eta=0,2$

e) prawdopodobieństwo zajścia krzyżowania $\kappa=1$

f) prawdopodobieństwo zajścia mutacji $\mu=0,05$

\begin{tabular}{|c|c|c|}
\hline $\begin{array}{c}\text { Stan } \\
\text { procesu }\end{array}$ & Decyzja "0" $-d_{i}^{(0)}$ & Decyzja $_{n}{ }^{\prime \prime}-d_{i}^{(1)}$ \\
\hline$S_{3}$ & $\begin{array}{c}\text { Trasa oznaczona kodem L } \\
\text { („lekkie" warunki realizacji zadania } \\
\text { przewozowego) }\end{array}$ & $\begin{array}{c}\text { Trasa oznaczona kodem T } \\
\text { („trudne" warunki realizacji zadania } \\
\text { przewozowego) }\end{array}$ \\
\hline$S_{5}$ & $\begin{array}{l}\text { Uzdatnianie przez PT typu P } \\
\text { (zakres podstawowy) }\end{array}$ & $\begin{array}{l}\text { Uzdatnianie przez PT typu R } \\
\text { (zakres rozszerzony) }\end{array}$ \\
\hline
\end{tabular}

Tabela 1. Decyzje w stanach analizowanego procesu 
Tabela 1. Decyzje w stanach analizowanego procesu (cd)

\begin{tabular}{|c|c|c|}
\hline$S_{6}$ & $\begin{array}{c}\text { Uzdatnianie przez PT typu P } \\
\text { (zakres podstawowy) }\end{array}$ & $\begin{array}{c}\text { Uzdatnianie przez PT typu R } \\
\text { (zakres rozszerzony) }\end{array}$ \\
\hline$S_{8}$ & $\begin{array}{c}\text { Uzdatnianie na stanowiskach PZZ typu N } \\
\text { (normalne) }\end{array}$ & $\begin{array}{c}\text { Uzdatnianie na stanowiskach PZZ typu I } \\
\text { (intensywne) }\end{array}$ \\
\hline$S_{9}$ & $\begin{array}{c}\text { Obsługiwanie na stanowisku OC typu N } \\
\text { (normalne) }\end{array}$ & $\begin{array}{c}\text { Obsługiwanie na stanowisku OC typu I } \\
\text { (intensywne) }\end{array}$ \\
\hline
\end{tabular}

Tabela 2. Oznaczenia kodowe decyzji oraz bezwarunkowe czasy trwania stanów procesu

\begin{tabular}{|c|c|c|c|c|}
\hline Stan procesu & $\boldsymbol{d}_{i}^{(0)}$ & $\boldsymbol{d}_{i}^{(1)}$ & $\boldsymbol{\Theta}_{i}^{(0)]}[\mathrm{h}]$ & $\boldsymbol{\Theta}_{i}^{(0)]}[\mathrm{h}]$ \\
\hline$S_{1}$ & 0 & 1 & 0,096 & 0,096 \\
\hline$S_{2}$ & 0 & 1 & 5,659 & 5,659 \\
\hline$S_{3}$ & 0 & 1 & 8,852 & 7,967 \\
\hline$S_{4}$ & 0 & 1 & 3,450 & 3,450 \\
\hline$S_{5}$ & 0 & 1 & 0,070 & 0,063 \\
\hline$S_{6}$ & 0 & 1 & 0,545 & 0,436 \\
\hline$S_{7}$ & 0 & 1 & 0,442 & 0,442 \\
\hline$S_{8}$ & 0 & 1 & 3,744 & 2,995 \\
\hline$S_{9}$ & 0 & 1 & 0,122 & 0,092 \\
\hline
\end{tabular}

Następnie wykonano obliczenia za pomocą opracowanego programu komputerowego z zastosowaniem algorytmu genetycznego, napisanego w: $R$ Development Core Team (2011). $R$ : A language and environment for statistical computing. $R$ Foundation for Statistical Computing, Vienna, Austria. ISBN 3-900051-07-0. W wyniku wykonanych obliczeń, dla przyjętego kryterium (11), wyznaczono optymalną strategię sterowania procesem eksploatacji realizowanym w badanym systemie eksploatacji środków transportu - systemie eksploatacji autobusów miejskich. Wynik obliczeń przedstawiono w tabeli 3.

Tabela 3. Optymalna strategia sterowania procesem eksploatacji środków transportu oraz wartość funkcji kryterialnej, wyznaczone na podstawie algorytmu genetycznego (dla przykładowych danych eksploatacyjnych)

\begin{tabular}{|c|c|}
\hline Strategia optymalna $\delta^{*}$ & $G^{O T}\left(\delta^{*}\right)$ \\
\hline$[1,1,1,0,0,1,0,0,1]$ & 0,8426 \\
\hline
\end{tabular}




\section{Podsumowanie}

W przedstawionej metodzie wyznaczenie optymalnej strategii sterowania procesem eksploatacji obiektów technicznych, polega na wyznaczeniu ciągu decyzji sterujących podejmowanych w poszczególnych stanach rozpatrywanego procesu eksploatacji, dla którego funkcja stanowiąca kryterium oceny osiąga wartość ekstremalną. Do wyznaczenia optymalnej strategii sterowania procesem eksploatacji obiektów technicznych zaproponowano zastosowanie algorytmu genetycznego. Ze względu na ogólny charakter, zaprezentowana metoda może zostać zastosowana do rozwiązywania szerokiej gamy zagadnień optymalizacyjnych dotyczących systemów eksploatacji obiektów technicznych, takich jak np.: analiza kosztów lub zysków, sterowanie gotowością i niezawodnością, analiza ryzyka i bezpieczeństwa działania itd. W każdym przypadku istnieje konieczność odpowiedniego zdefiniowania funkcji kryterialnej oraz określenia możliwych decyzji sterujących podejmowanych w stanach badanego procesu eksploatacji obiektów technicznych.

Przedstawiony w artykule sposób wyznaczania optymalnej strategii sterowania procesem eksploatacji obiektów technicznych z wykorzystaniem algorytmu genetycznego, stanowi jeden z etapów prac, których celem jest opracowanie kompleksowej metody sterowania procesem eksploatacji obiektów technicznych z zastosowaniem modeli decyzyjnych. Kompleksowa metoda sterowania procesem eksploatacji środków transportu ma umożliwić sterowanie zarówno procesami realizowanymi w podsystemie wykonawczym (ocena realizacji zadań przewozowych) oraz w podsystemie zapewniania zdatności (ocena realizacji zadań obsługowo-naprawczych), z uwzględnieniem zarówno kryteriów technicznych i ekonomicznych funkcjonowania tego typu systemów eksploatacji.

\section{Literatura}

[1] DAVIS, L.D.: Handbook of genetic algorithms. Van Nostrand Reinhold 1991.

[2] GRABSKI, F., JAŹWIŃSKI, J.: Funkcje o losowych argumentach w zagadnieniach niezawodności, bezpieczeństwa i logistyki. WKit. Warszawa 2009.

[3] GOLDBERG, D. E.: Algorytmy genetyczne i ich zastosowanie. WNT. Warszawa 2003.

[4] JAŹWIŃSKI, J., GRABSKI, F.: Niektóre problemy modelowania systemów transportowych. Instytut Technologii Eksploatacji. Warszawa-Radom 2003.

[5] KOROLUK, V. S.: Modele stochastyczne systemów. Naukova Dumka. Kiev 1989.

[6] KOROLUK, V. S., TURBIN, A. F.: Semi-Markov processes and their application. Naukova Dumka. Kiev 1976.

[7] KOWALENKO, I. N., KUZNIECOW, N. J., SZURIENKOW, W. M.: Procesy stochastyczne. Poradnik. PWN. Warszawa 1989.

[8] KULKARNI, V. G.: Modeling and analysis of stochastic systems. Chapman \& Hall. New York 1995.

[9] KUSIAK, J., DANIELEWSKA-TUŁECKA, A., OPROCHA, P.: Optymalizacja. Wybrane metody z przykładami zastosowań. PWN. Warszawa 2009.

[10] MICHAELEWICZ, Z.: Genetic algorithms + data structure = evolution programs. Springer Verlag. Berlin 1996.

[11] MIGAWA, K.: Semi-Markov model of the availability of the means of municipal transport system. Zagadnienia Eksploatacji Maszyn, 3(159), vol. 44, Radom 2009.

[12] MIGAWA, K.: Method for control of technical objects operation process with the use of semi-Markov decision processes. Journal of KONES Powertrain and Transport, vol. 19, no. 4, 2012.

[13] MITCHELL, M.: An introduction to genetic algorithms. MIT Press. Cambridge 1996.

[14] VOSE, M.D.: The simple genetic algorithm. Foundations and theory. MIT Press. Cambridge 1998. 